\title{
THE DEVELOPMENT OF SUDANESE GRASS AND ITS PHOTOSYNTHETIC ACTIVITY DEPENDS ON THE DURATION OF PLANTING
}

\author{
Khalima Nazarovna Atabaeva ${ }^{1}$ and Davron Mamatkulovich Mustafakulov ${ }^{2}$ \\ ${ }^{1}$ Doctor of Agricultural Sciences, Professor of the Department Soybean and Oilseed Crops, \\ Tashkent State Agrarian University, Tashkent, Uzbekistan \\ ${ }_{2}^{2}$ Independent Researcher, Senior Teacher of the Department Soybean and Oilseed Crops, \\ Tashkent State Agrarian University, Tashkent, Uzbekistan
}

https://doi.org/10.35410/IJAEB.2020.5561

\begin{abstract}
The experiments show that, if the soil of the plant at the beginning of the period of application of the soil of the sudanese grass was $169-176$ units $/ \mathrm{m} 2$ in terms of planting times, so the level of soil was increased from 2,09 to 4,04 during the first planting period. The number of plows per bush decreased from the first planting period to the last planting period, but increased from harvest to harvest. During the first planting period, the number of shrubs in the first place increased from 359 pieces to 695 pieces in the fourth. During the second planting period, it was found that it increased from 365 to 578 pieces.
\end{abstract}

Keywords: Sudanese grass, planting times, photosynthetic activity, green mass, leaf surface.

\section{INTRODUCTION}

Sudanese grass is a one-year ringing grass. It is a drought-resistant, high-nutrient grass that is fully eaten by livestock. Sudanese grass is sown for growing greens, hay, silage, senage and seedling. Green harvest is 60-80 tonnes and seed harvest is 2,5 tonnes. In 100 kilograms of greens there are 22 units of nutrients and $2,8 \mathrm{~kg}$ of protein, and in the hay respectively 57 units of nutrients and 7,4 $\mathrm{kg}$ of protein [1].

The reproduction coefficient of Sudan grass is high: $15-20 \mathrm{~kg}$ of seeds per hectare can be harvested 20-30 centner/ha. Sudanese grass belongs to the Poaceae family, sorghum constellation and sudanense P. per. by type. Its Homeland is Sudan (Africa). It has been cultivated in Uzbekistan since the 20th century. It is common in tropical and subtropical regions.

The root is well developed as a tassel root, The root penetrates to a depth of 2-2, $5 \mathrm{~m}$ and $70 \mathrm{~cm}$ spreads to the side. Sudanese grass perfectly absorbs the nutrients of the soil.

It is a heat-loving plant, the seed sprouts at $8-10^{\circ} \mathrm{C}$, alternate cure stops growing at $25^{\circ} \mathrm{C}$, if the temperature is $45^{\circ} \mathrm{C}$. The sum of useful temperature is $1500-3000^{\circ} \mathrm{C}$, the plant dies in the cold $3-4^{\circ} \mathrm{C}$. Sudanese grass is a drought-resistant plant, but when watered it grows well and gives a high yield. 
Sudanese grass grows well on clean, fertile soils, is resistant to salination, is demanding in food. To grow a ton of hay, $20-22 \mathrm{~kg}$ of nitrogen, $8-10 \mathrm{~kg}$ of phosphorus and $20 \mathrm{~kg}$ of potassium are spent. At the beginning of the growth period, the plant grows slowly. The height of the shrub during the period of cultivation is $18-25 \mathrm{~cm}$ [2].

If alternative agrotechnical measures are carried out in the cultivation of Sudanese grass, a high green crop is obtained. It is necessary to determine the technological elements in each soilclimatic condition for Sudanese grass. One of the technological elements that sharply affects the harvest is the duration of planting. From the biology it is known - this is a heat-loving plant, so the earliest planting times are determined depending on the biology.

A.G.Shapoval recommends planting Sudanese grass in the Crimea, the North Caucasus regions by the end of April and the beginning of May, as it is possible to start planting at $10-12^{\circ} \mathrm{C}$, having studied the duration of planting of Sudanese grass. It is recommended to plant in the south of Ukraine-in early May, and in the north - in middle May [3].

In the steppe regions of Kazakhstan, the Sudanese grass is an important fodder crop, with great emphasis on the technology of its cultivation. Hay was taken to 17,39-22.06 c/ha when sown in the early term. In many regions, it is recommended to plant Sudanese grass in $10^{\circ} \mathrm{C}$ temperature $[4,5]$. In Latfullin's experiments, a high yield was obtained when Sudanese grass was sown on 25 May and 5 June - to 4,82-5,18 tonn/ha. When the Sudanese grass was planted at 15-20.05, the yield decreased by $9-16 \%[10]$.

In the scientific work carried out at the Turkmen farming institute, the planting periods of Sudanese grass are pointed as 19 March, and it is sown on 1st, 10th, 19th April. When sown in the first term, the seedlings appeared in 14 day, and in the remaining terms appeared in 6-10 day. The height of the stem varies from $76 \mathrm{~cm}$ to $156 \mathrm{~cm}$. The leaves were $37-41 \%$ [7].

The first experiments on the Sudanese grass in Uzbekistan were conducted in 1928-1929 in the Kattakurgan District of Samarkand region and the optimal planting period of the Sudanese grass was determined. Acceptable planting time is counted as 5 April. The good soil and re-growth of the Sudanese grass is an important factor in increasing the yield, after the last harvest, the Sudanese grass can be used as a residue. In the lower parts of the semi-supplied watered land, hay can be grown from Sudan grass to $10 \mathrm{c} / \mathrm{ha}$. In 1932-1933, the Milyutin experiment station studied the planting times of Sudanese grass, and in one season 2th harvest was obtained [2, 5].

Due to the biology of the Sudanese grass, it is recommended to plant the period of planting of the Sudanese grass when $10^{\circ} \mathrm{C}$ at the depth of planting of the soil. In the climates, this is from April to the first ten days of May and June. Due to the fact that the planting time is different according to the agro calendar, 1-3 times from the Sudanese grass, under irrigated conditions it is possible to harvest $4-5$ times.

\section{MATERIALS AND METHODS}

Experiments on the period of sowing of soybean were carried out in the scientific-practical work of the Institute of cotton selection, seed growing and agrotechnologies of cultivation in Mirzaabad district, Sirdarya region. Summer in the territory of Sirdarya region is hot and dry, 
winter is moderate, and there is also a big difference between the daily and annual temperatures. The average annual temperature in the region is around $+12,9+14,9^{\circ} \mathrm{C}$. The highest temperature indicator is in June-July, it reaches $+25,4+29,5^{\circ} \mathrm{C}$, while the coldest indicator is in December, January, and is around $1,8-0,1^{\circ} \mathrm{C}$. The decline in temperature in winter is associated with the penetration of cold air flows from the Fergana Valley. The soil temperature (in the soil layer) in winter, on average in January $-2-0,2{ }^{\circ} \mathrm{C}$, the soil surface freezes, which makes it difficult to plow the soil and wash the brine. The first frost falls on November, and the last frost falls on February. The duration of cold-free days is 200-336 days.

The sirdarya region is located in the zone where strong wind movements intersect, and the North and East (Bekabad wind) influence on the region is strong. The main part of the wind blows more than in the East and most often falls on May-June. The speed of the wind reaches 3,2 $\mathrm{m}$ per second. In the field of experience, Boz-Meadow soils are distributed, which in the region amounts to 232472 hectares or $54,3 \%$.

In terms of salinity of Boz-Meadow soils of Mirzaabad district, the amount of washed and weakly saline soils is $36.9 \%$, in average the amount of saline soils is $45.9 \%$, in strong and very strong saline soils $11.7 \%$. We observed the amount of nutrients in experimental field soils at the beginning and end of vegetation of crops.

The amount of humus in the arable layer of soils of the described area is $0,534-0,614 \%$, in the arable underground layers $0,427-0,453 \%$.

Table 1 .The amount of nutrients in the soil (before planting)

\begin{tabular}{|c|c|c|c|c|c|c|c|c|}
\hline \multirow{2}{*}{ Cutting } & \multirow{2}{*}{$\begin{array}{l}\text { Layer, } \\
\text { cm }\end{array}$} & \multicolumn{4}{|c|}{ Total, \% } & \multicolumn{3}{|c|}{ Moving, mg/kg } \\
\hline & & Humus & $N$ & $P$ & $K$ & $\mathrm{~N}-\mathrm{NO}_{3}$ & $\overline{\mathrm{P}_{2} \mathrm{O}_{5}}$ & $\mathrm{~K}_{2} \mathrm{O}$ \\
\hline \multirow{2}{*}{1} & $0-30$ & 0,534 & 0,044 & 0,100 & 1,75 & 1,70 & 20,0 & 125 \\
\hline & $30-50$ & 0,427 & 0,036 & 0,085 & 1,80 & 1,50 & 18,0 & 125 \\
\hline \multirow{2}{*}{2} & $0-30$ & 0,480 & 0,040 & 0,090 & 1,70 & 2,81 & 40,0 & 150 \\
\hline & $30-50$ & 0,400 & 0,030 & 0,070 & 1,75 & 1,91 & 25,0 & 150 \\
\hline \multirow{2}{*}{3} & $0-30$ & 0,614 & 0,053 & 0,126 & 1,78 & 2,135 & 42,5 & 125 \\
\hline & $30-50$ & 0,453 & 0,042 & 0,100 & 1,80 & 1,91 & 30,0 & 125 \\
\hline
\end{tabular}

After sowing, the supply of nutrients to the soil is slightly improved.

The experiment was conducted in the laboratory and field style. Field experiments placed in 4 repetitions, 2 tiers. The surface of the socks is $36 \mathrm{~m} 2$. Periods of planting of Sudanese grass: $01.04 ; 15.04 ; 01.05$ and $15.05 ; 01.06$ and $15.06 ; 01.07$ and 15.07 ; 01.08. The planting norm of seeds is up to $25 \mathrm{~kg} / \mathrm{ha}$, the planting depth is $3-5 \mathrm{~cm}$. Planting method is simple as follows, between rows $15 \mathrm{~cm}$. In the experiment, the Chimbayskaya Jubilee variety was planted. All 
agrotechnical activities remaining in the experiment were carried out according to the technology of cultivation adopted in the region.

Table 2 .The amount of nutrients in the soil at the end of vegetation

\begin{tabular}{|c|c|c|c|c|c|c|c|}
\hline \multirow{3}{*}{ Cutting } & \multirow{3}{*}{$\begin{array}{l}\text { Layer, } \\
\mathrm{cm}\end{array}$} & \multicolumn{3}{|c|}{ Total, \% } & \multicolumn{3}{|c|}{ Moving, mg/kg } \\
\hline & & Humus & $N$ & $P$ & $\mathrm{~N}-\mathrm{NO}_{3}$ & $\mathrm{P}_{2} \mathrm{O}_{5}$ & $\mathrm{~K}_{2} \mathrm{O}$ \\
\hline & & $\%$ & $\%$ & $\%$ & МГ/КГ & МГ/КI & \\
\hline \multirow[t]{2}{*}{1} & $0-30$ & 0,582 & 0,046 & 0,082 & 0,75 & 12,1 & 134 \\
\hline & $30-50$ & 0,480 & 0,021 & 0,055 & 1,10 & 7,6 & 134 \\
\hline \multirow[t]{2}{*}{2} & $\begin{array}{l}0-30 \\
\end{array}$ & 0,515 & 0,038 & 0,076 & 1,91 & 8,5 & 100 \\
\hline & $30-50$ & 0,334 & 0,013 & 0,055 & 1,50 & 6,0 & 100 \\
\hline \multirow[t]{2}{*}{3} & $0-30$ & 0,637 & 0,036 & 0,082 & 3,26 & 10,0 & 168 \\
\hline & $30-50$ & 0,425 & 0,030 & 0,060 & 1,50 & 10,0 & 168 \\
\hline
\end{tabular}

In the experiment, phenological observations, biometric measurements, calculations were performed, yield and its quality were determined in the period of application [8].

\section{RESULTS AND DISCUSSION}

Sudanese grass has the property of piling up. At the beginning of the period of application, it was determined that the seedling number of the plant was $169-176$ units $/ \mathrm{m} 2$ in terms of planting times. During the first planting period, the level of salinity of the Sudanese grass increased from 2,09 to 4,04 from harvest. It was found that the soil decreased during the next planting periods (Table 3). It has been observed that during all planting periods, there is an increase in the number of seedlings to harvest.

Table 3 The effect of planting time on the seedling number and piling up of Sudanese grass

\begin{tabular}{|c|c|c|c|c|c|c|c|c|c|}
\hline \multirow{3}{*}{$\begin{array}{l}\text { Term of } \\
\text { planting }\end{array}$} & \multirow{3}{*}{$\begin{array}{l}\begin{array}{l}\text { Number } \\
\text { of } \\
\text { seedlings }\end{array} \\
\mathrm{M}^{2} / \text { plant }\end{array}$} & \multicolumn{4}{|c|}{ General piling up } & \multicolumn{4}{|c|}{ The number of stems, $\mathrm{M}^{2} /$ plant } \\
\hline & & \multicolumn{8}{|c|}{ Cuttings } \\
\hline & & 1 & 2 & 3 & 4 & 1 & 2 & 3 & 4 \\
\hline 01.04 & 172 & 2,09 & 2,58 & 3,30 & 4,04 & 359 & 444 & 568 & 695 \\
\hline 15.04 & 172 & 2,12 & 2,65 & 3,36 & - & 365 & 447 & 578 & - \\
\hline
\end{tabular}


Vol. 5, No. 05; 2020

ISSN: $2456-8643$

\begin{tabular}{|l|l|l|l|l|l|l|l|l|l|}
\hline 01.05 & 171 & 2,08 & 2,61 & 3,19 & - & 356 & 446 & 545 & - \\
\hline 15.05 & 169 & 2,14 & 2,68 & 3,34 & - & 362 & 453 & 564 & - \\
\hline 01.06 & 170 & 2,01 & 2,59 & - & - & 342 & 440 & - & - \\
\hline 15.06 & 171 & 2,01 & 2,46 & - & - & 344 & 421 & - & - \\
\hline 01.07 & 172 & 2,02 & 2,32 & - & - & 347 & 399 & - & - \\
\hline 15.07 & 171 & 2,06 & 2,09 & - & - & 352 & 357 & - & - \\
\hline
\end{tabular}

The number of plows per bush decreased from the first planting period to the last planting period, but increased from harvest to harvest. During the first planting period, the number of shrubs in the first place increased from 359 grains to 695 pieces in the fourth. During the second planting period, it increased from 365 to 578 pieces. There is almost no difference in the number of shares in the term of the last planting.

Sudanese grass is a tall plant, but it is harvested early to obtain a green mass, so the biological capacity is not enough. In the early planting periods, it grew better in the second and third harvests, since these harvests coincided with the high harnesses of the summer. When planted in the second half of summer, only in the first place grew well (Table 4).

Table 4 The growth of Sudanese grass and its dependence on the duration of planting of the leaf surface

\begin{tabular}{|c|c|c|c|c|c|c|c|c|c|}
\hline \multirow{3}{*}{$\begin{array}{l}\text { Term of } \\
\text { planting }\end{array}$} & \multicolumn{4}{|c|}{ Stem height,sm } & \multicolumn{4}{|c|}{ Leaf surface, ths $\mathrm{m} 2 / \mathrm{ha}$} & \multirow{3}{*}{$\begin{array}{l}\text { Photosynthetic } \\
\text { capacity } \\
\text { (PSC), mln. } \text { M }^{2} \\
\text { day/ha }\end{array}$} \\
\hline & \multicolumn{8}{|c|}{ cuttings } & \\
\hline & 1 & 2 & 3 & 4 & 1 & 2 & 3 & 4 & \\
\hline 01.04 & 159 & 170 & 160 & 130 & 14,4 & 17,8 & 22,7 & 27,8 & 1,48 \\
\hline 15.04 & 158 & 168 & 152 & 153 & 18,2 & 22,7 & 28,0 & 22,2 & 1,48 \\
\hline 01.05 & 153 & 160 & 146 & 48 & 17,8 & 22,3 & 27,2 & - & 1,40 \\
\hline 15.05 & 152 & 156 & 152 & 46 & 17,6 & 22,1 & 26,6 & - & 1,29 \\
\hline 01.06 & 150 & 150 & 144 & - & 17,2 & 22,1 & 22,2 & - & 1,22 \\
\hline 15.06 & 155 & 155 & 56 & - & 20,6 & 25,2 & - & - & 1,06 \\
\hline 01.07 & 150 & 110 & - & - & 21,0 & 23,4 & - & - & 0,90 \\
\hline
\end{tabular}




\begin{tabular}{|l|l|l|l|l|l|l|l|l|l|}
\hline 15.07 & 177 & 55 & - & & 14,1 & 14,4 & - & - & 0,41 \\
\hline
\end{tabular}

As you know, the yield is higher if the leaf surface is well developed. In the experiment, the leaf surface was determined in each mowing. During the first planting period, the leaf surface increased from 14,4 to 27,8 thousand $\mathrm{m} 2 /$ ha. During the second planting period, it was found that in the last harvest the leaf surface decreased, in this case the duration of this harvest was reduced. In the third, fourth and fifth planting periods, three harvests were obtained, but in the fifth planting period, the duration of the third harvest was short, did not reach the mowing phase. In the sixth-eighth harvests were harvested from two, but did not reach the optimal harvesting phase in the last term. Total leaf surface planting times correspond to the options for all harvests 82.7; 91,$1 ; 67,3 ; 66,3 ; 61,5 ; 45,8 ; 44,0 ; 28,5$ it was equal to a thousand $\mathrm{m} 2 / \mathrm{ha}$. Another indicator of the photosynthetic activity of crops is the photosynthetic capacity (PSC). In the experiment, PSC decreased planting times from 1,48 to 0,41 million $\mathrm{m} 2$ per day. This affects productivity.

Planting times were affected by the harvest of greens extracted from the Sudanese grass. This can be seen from the data in Table 5. A good harvest was obtained in 3 units of the first planting period, but in the last harvest the harvest was $94 \mathrm{c} / \mathrm{ha}$, since the last harvest did not reach the optimal harvesting phase. When sown in May, 3 units were harvested, the yield of the third crop was reduced. When sown in June, 2th harvest was taken, the third harvest was also taken when sown in early June, but the harvest was low. When sown in the second half of July, one harvest was obtained, the this case, received Greens to $198 \mathrm{c} / \mathrm{ha}$. In the period of validity in the Sudanese grass, the total harvest of Greens obtained by planting periods is appropriate to the options: 761; $684 ; 610 ; 531 ; 452 ; 368 ; 311 ; 198 \mathrm{c} / \mathrm{ha}$. The poppy of the Sudanese grass is a nutritious food. The unit of nutrients obtained by planting periods in terms of options in total yield: 146,0;130,7; 116,$0 ; 100,4 ; 78,8 ; 67,2 ; 57,0 ; 33,7$ established $\mathrm{c} / \mathrm{ha}$. The amount of nutrients, like the amount of harvest, also decreased as late planted.

Table 5 The dependence of the yield of the green mass of the Sudanese grass and the amount of unit of nutrients on the duration of planting

\begin{tabular}{|c|c|c|c|c|c|c|c|c|c|c|}
\hline \multirow{3}{*}{$\begin{array}{l}\text { Term of } \\
\text { planting }\end{array}$} & \multicolumn{5}{|c|}{ Green mass harvest, c/ha } & \multicolumn{5}{|c|}{ Feed unit, c/ha } \\
\hline & \multicolumn{4}{|c|}{ cuts } & \multirow{2}{*}{ total } & \multicolumn{4}{|l|}{ cuts } & \multirow{2}{*}{ total } \\
\hline & 1 & 2 & 3 & 4 & & 1 & 2 & 3 & 4 & \\
\hline 01.04 & 206 & 243 & 218 & 94 & 761 & 35,0 & 48,6 & 43,6 & 18,9 & 146,0 \\
\hline 15.04 & 204 & 241 & 212 & 27 & 684 & 34,7 & 40,2 & 40,4 & 6,4 & 130,7 \\
\hline 01.05 & 200 & 240 & 170 & & 610 & 34,0 & 48,0 & 34,0 & & 116,0 \\
\hline 15.05 & 195 & 226 & 109 & & 531 & 33,2 & 46,6 & 21,6 & & 100,4 \\
\hline
\end{tabular}


International Journal of Agriculture, Environment and Bioresearch

Vol. 5, No. 05; 2020

ISSN: $2456-8643$

\begin{tabular}{|l|l|l|l|l|l|l|l|l|l|l|}
\hline 01.06 & 192 & 221 & 39 & & 452 & 32,6 & 44,2 & & & 78,8 \\
\hline 15.06 & 183 & 177 & - & & 368 & 32,0 & 35,2 & & & 67,2 \\
\hline 01.07 & 174 & 137 & - & & 311 & 29,6 & 27,4 & & & 57,0 \\
\hline 15.07 & 198 & - & - & & 196 & 33,7 & & & & 33,7 \\
\hline
\end{tabular}

In terms of options per unit on a feed in this experiment 94; 93; 93;92;90;89;88;76; 77 gram protein is correct. According to the zoo technical requirements, 100-110 grams of protein per unit of feed should fit. The fullness of the greens from the Sudanese grass depends on the duration of planting, and when planted early, this is approaching the demand, which means that it is much cheaper to feed the cattle.

\section{CONCLUSIONS}

In the experiment, it was found that by the periods of planting, the level of salinity of the Sudanese grass increases, from the harvest to the harvest, which means the possibility of obtaining higher Greens;

From the early planting periods, there was a decrease in the leaf surface and photosynthetic capacity, depending on the late planting periods.

The period of planting of the crop has been decreasing late. The total yield decreased from 761 to $196 \mathrm{c} / \mathrm{ha}$.

The presence of a nutrient unit from 145,0 to $33,7 \mathrm{c} /$ ha was determined in the case, depending on the planting time in the sprouts of the Sudanese grass.

\section{REFERENCES}

[1] Atabaeva Kh.N., Khudoykulov J.B. Plant Science. Tashkent, "Fan va Tekhnologiya", (2018), p.255. (In Uzbek)

[2] Umarov Z.U., Atabaeva Kh.N., Gumirov I.N. Forage grasses of Central Asia. Tashkent, TashSHI, (1990), p. 59. (In Russ.)

[3]Shapoval A.G. Sorgo (Sorghum). Moscow-Leningrad, Gosizdat Sel-Khoz. Literature, (1981), p. 170. (In Russ.)

[4]Agrotechnology of Sudanese grass. https://fermer.ru/sovet/kormovye-rasteniya/20430, 11.03.2009 (In Russ.)

[5]Karpov N. Agrotechnics of forage crops on bogara. Tashkent, Gosizdat, (1935), p. 68. (In Russ.) 
[6]Nasiyev B.N., Zhanatalapov N.G. Sowing times of sudanian grass in the area of dry steppe. Agrarian science. No 2, (2020), pp. 53-55. (In Russ.) https://doi.org/10.32634/0869-8155-2020$335-2-53-55$

[7]Ovezmurodov S.O., Makunyan O.M. On the timing of sowing Sudanese grass. The journal "Agriculture of Turkmenistan" (Selskoe khozyaystvo Turkmenistana), No 2, (1958), pp. 41-44. (In Russ.)

[8]Dospekhov B.A. The Methodology of field experience. 5th edition, Moscow, Agropromizdat, (1985), p. 351.

[9]Dubenok N.N., Borodichev V.V., Dedova E.B., Kravchenko E.A. Technology of cultivation of Sudanese grass for hay on brown semi-desert soils of Kalmykia. Dostyjeniya nauki I tekhniki APK (Achievements of science and technics of the agro-industrial complex), №2, (2014), pp. 4953. (In Russ.)

[10]Latfullin V.Z. Sowing methods of Sudanese grass in the Middle Urals. Dissertation Abstract: general agriculture, crop production, UFA, Bashkir State Agrarian University, (2015), p. 20. (In Russ.)

[11]Mardvakov N.B. Influence of seeding rates and sowing dates on the yield and quality of Sudanese grass in the dry steppe zone of Buryatia. Dissertation Abstract: general agriculture, crop production, Ulan-ude, (2011), p. 21. (In Russ.) 